\title{
Comparison of the efficacy of biodegradable and non-biodegradable scintillation liquids on the counting of tritium- and $\left[{ }^{14} \mathrm{C}\right]$-labeled compounds
}

\footnotetext{
R.B. Medeiros ${ }^{1}$,

R.O. Godinho ${ }^{2}$ and

M.F.S.S. Mattos ${ }^{1}$
}

\author{
${ }^{1}$ Unidade de Proteção Radiológica and ${ }^{2}$ Departamento de Farmacologia, \\ Escola Paulista de Medicina, Universidade Federal de São Paulo, \\ São Paulo, SP, Brasil
}

\section{Correspondence \\ R.B. Medeiros \\ Unidade de Proteção Radiológica EPM, UNIFESP \\ Rua Botucatu, 659 \\ 04023-900 São Paulo, SP \\ Brazil \\ Fax: +55-11-5539-4208 \\ E-mail: rbitelli.ddi@epm.br}

Research supported by the Fundo de Auxílio aos Docentes e Alunos (FADA), UNIFESP/EPM.

Publication supported by FAPESP.

Received August 29, 2002 Accepted September 3, 2003

\begin{abstract}
The widespread use of ${ }^{3} \mathrm{H}$ and ${ }^{14} \mathrm{C}$ in research has generated a large volume of waste mixed with scintillation liquid, requiring an effective control and appropriate storage of liquid radioactive waste. In the present study, we compared the efficacy of three commercially available scintillation liquids, Optiphase HiSafe 3, Ultima-Gold ${ }^{\mathrm{TM}}$ AB (biodegradable) and Insta-Gel-XF (non-biodegradable), in terms of $\left[{ }^{14} \mathrm{C}\right]$-glucose and $\left[{ }^{3} \mathrm{H}\right]$-thymidine counting efficiency. We also analyzed the effect of the relative amount of water (1.6 to 50\%), radioisotope concentration ( 0.1 to $100 \mathrm{nCi} / \mathrm{ml}), \mathrm{pH}$ (2 to 10$)$ and color of the solutions (samples containing 0.1 to $1.0 \mathrm{mg} / \mathrm{ml}$ of Trypan blue) on the counting efficiency in the presence of these scintillation liquids. There were few significant differences in the efficiency of ${ }^{14} \mathrm{C}$ and ${ }^{3} \mathrm{H}$ counting obtained with biodegradable or non-biodegradable scintillation liquids. However, there was an 83 and $94 \%$ reduction in the efficiency of ${ }^{14} \mathrm{C}$ and ${ }^{3} \mathrm{H}$ counting, respectively, in samples colored with $1 \mathrm{mg} / \mathrm{ml}$ Trypan blue, but not with $0.1 \mathrm{mg} / \mathrm{ml}$, independent of the scintillation liquid used. Considering the low cost of biodegradable scintillation cocktails and their efficacy, these results show that traditional hazardous scintillation fluids may be replaced with the new safe biodegradable fluids without impairment of ${ }^{3} \mathrm{H}$ and ${ }^{14} \mathrm{C}$ counting efficiency. The use of biodegradable scintillation cocktails minimizes both human and environmental exposure to hazardous solvents. In addition, some biodegradable scintillation liquids can be $40 \%$ less expensive than the traditional hazardous cocktails.
\end{abstract}

\section{Introduction}

Radioisotopes commonly used in biomedical research possess low energy and a short range of air or fluid penetration. Therefore, they require direct contact with the scintillation medium and special technology
Key words

- Biodegradable chemicals

- Scintillation liquids

- Liquid waste

- Color quenching

- Scintillation counting

efficiency

- Tritium and ${ }^{14} \mathrm{C}$ counting 
radioactive waste that results from techniques such as radioimmunoassay or radioligand binding assays. Most of these experiments generate a large volume of ${ }^{3} \mathrm{H}$ and ${ }^{14} \mathrm{C}$ waste in scintillation liquid.

For an ideal liquid scintillation detector, the amount of light generated must be proportional to the energy transferred and the detection should be perfectly linear. However, an energy transfer loss frequently occurs as a result of absorption of light by solid materials, chromogenic interposition, solution turbidity or $\mathrm{pH}$ changes in the scintillation fluid $(2,3)$.

The process of radioactive detection involves scintillation fluids composed of aromatic solvents that increase the efficiency of energy transfer to the organic fluorine compound, improving the detection of light emission. Table 1 lists commercially available scintillation cocktails and their characteristics based on technical charts provided by the manufacturers. The primary and most extensively used scintillation fluid contains 2,5-diphenyloxazole, and is known as PPO. In fact, secondary compounds such as 1,4bis(5-phenyl-2-oxazolyl)-benzene are also included in the scintillation fluid in order to absorb the light emitted by the PPO, properly distribute the light and enhance the detection process (4). Toluene, xylene and dioxane are also widely used for this purpose (5). These inflammable and extremely toxic solvents represent a risk to laboratory activities, which is aggravated by the inappropriate storage of large amounts of hazardous liquids in the work place, since these liquids cannot simply be dumped into the public sewage system and their incineration is too costly (5). Finally, the liquid associated with radioisotopes is also considered radioactive waste that must be processed according to radioprotection laws (6).

The Radiological Protection Unit of UNIFESP/Sociedade Paulista para o Desenvolvimento da Medicina/Hospital São Paulo (UNIFESP/SPDM/HSP) recommends standardized procedures that fulfill current legislation and minimize safety problems in research laboratories (available at http:// protecaoradiologica.unifesp.br). Scintillation fluids with special formulations are now commercially available and have been considered safe because of their reduced aromatic content and biodegradability. However, the traditional use of well-established non-bio-

Table 1. Chemical characteristics and properties of scintillation liquids.

\begin{tabular}{|c|c|c|c|}
\hline & Insta-Gel-XF & Ultima-Gold ${ }^{T M} A B$ & Optiphase HiSafe 3 \\
\hline Biodegradability & No & $70 \%$ biodegradable after 28 days & $80 \%$ biodegradable after 28 days \\
\hline Substance family & $\begin{array}{l}\text { 1,2,4-Trimethylbenzene mixed, } \\
\text { liquids and detergents }\end{array}$ & $\begin{array}{l}\text { Diisopropylnaphthalene mixed, } \\
\text { liquids and detergents }\end{array}$ & $\begin{array}{l}\text { Diisopropylnaphthalene mixed, liquids } \\
\text { and detergents }\end{array}$ \\
\hline Hazards identification & $\begin{array}{l}\text { Flammable, harmful by } \\
\text { inhalation, irritating to eyes, } \\
\text { skin and respiratory system }\end{array}$ & $\begin{array}{l}\text { Flammable, irritating to skin } \\
\text { and eyes }\end{array}$ & $\begin{array}{l}\text { Irritating to skin, eyes, and respiratory } \\
\text { system }\end{array}$ \\
\hline Mutagenic & No & No & No \\
\hline Carcinogenic & No & No & No \\
\hline Teratogenic & No & No & No \\
\hline Recommended discard & Incineration & $\begin{array}{l}\text { Discard according to national } \\
\text { legislation }\end{array}$ & $\begin{array}{l}\text { Discard according to national } \\
\text { legislation }\end{array}$ \\
\hline Price for 10 liters & US\$ 380.00 & US\$ 383.00 & US\$ 226.00 \\
\hline
\end{tabular}

Data obtained from the manufacturer's Material Safety Data Sheet. Prices obtained from March to April, 2003. 
degradable scintillation liquids and the resistance to change in laboratory routines hamper the acceptance of biodegradable scintillation liquids as solution for some of the safety problems and for the costly incineration of toxic laboratory wastes.

Therefore, we assessed the efficiency of biodegradable aqueous scintillation liquids and compared them to the liquids conventionally used in our laboratories for which the only disposal option is incineration. The aim of the present study was to determine, on the basis of counting efficiency, appropriate conditions for the use of biodegradable liquids. In addition, we propose to bring to the attention of the scientific community the advantages of biodegradable scintillation liquids over non-biodegradable liquids, because there is guaranteed adequate disposal of biodegradable radioactive waste according to Comissão Nacional de Energia Nuclear (CNEN) rules for radioprotection and environmental conservation.

\section{Material and Method}

The influence of the relative amount of aqueous solution, radioisotope concentration, $\mathrm{pH}$ and solution color on the detection of radioactivity emitted by $\left[{ }^{3} \mathrm{H}\right]$-thymidine or $\left[{ }^{14} \mathrm{C}\right]$-glucose was determined for several commercially available scintillation fluids: Insta-Gel-XF, Ultima-Gold ${ }^{\mathrm{TM}} \mathrm{AB}$ (Packard Biosciences B.V. Chemical Operations, Ulgersmaweg, Groningen, Netherlands) and Optiphase HiSafe 3 (Perkin Elmer Life Science/Wallac Oy, Mustionkatu, Turku, Finland). All experiments were carried out in quadruplicate. The results are reported as mean \pm SEM radioactivity measured as disintegration per minute. Statistical differences among groups were determined by analysis of variance (ANOVA) followed by the Newman-Keuls test, with the level of significance set at $\mathrm{P}<0.05$. When necessary, a linear regression analysis was performed.
Effect of the relative amount of water on counting efficiency

In order to analyze the influence of the relative amount of water solution on counting efficiency, $3700 \mathrm{~Bq}(100 \mathrm{nCi})\left[{ }^{14} \mathrm{C}\right]-$ glucose or $0.037 \mathrm{MBq}(1.0 \mu \mathrm{Ci})\left[{ }^{3} \mathrm{H}\right]$-thymidine was diluted in a final volume of $6 \mathrm{ml}$ containing 0.1 to $3 \mathrm{ml}$ of water and the various scintillation liquids. The aqueous solutions corresponded to 1.6, 8.3, 16.7, 25, 33.3 and $50 \%$ of the final volume. The vials were vortexed and the radioactivity was determined with a scintillation counter.

\section{Effect of the concentration of radiolabeled compound on counting efficiency}

For the determination of radioactivity as a function of radioisotope concentration, 0.1 , 1,10 , and $100 \mathrm{nCi}\left[{ }^{3} \mathrm{H}\right]$-thymidine or $\left[{ }^{14} \mathrm{C}\right]-$ glucose diluted in $1 \mathrm{ml}$ of water were added to vials containing $5 \mathrm{ml}$ Insta-Gel-XF, Optiphase HiSafe 3 or Ultima-Gold ${ }^{\mathrm{TM}} \mathrm{AB}$ scintillation fluids. The vials were vortexed and radioactivity was determined with a scintillation counter.

\section{Effect of solution pH on counting efficiency}

In this set of experiments, the influence of $\mathrm{pH}$ was determined by diluting $100 \mathrm{nCi}$ $\left[{ }^{3} \mathrm{H}\right]$-thymidine or $\left[{ }^{14} \mathrm{C}\right]$-glucose in $1 \mathrm{ml}$ of phosphate-buffered saline, $\mathrm{pH}$ 7.0, glycine$\mathrm{HCl}$ buffer, $\mathrm{pH} 2.0$, or borate buffer, $\mathrm{pH}$ 10.0. Subsequently, $5 \mathrm{ml}$ of the scintillation liquids Insta-Gel-XF, Optiphase HiSafe 3 and Ultima-Gold ${ }^{\mathrm{TM}} \mathrm{AB}$ were added, vials were vortexed and radioactivity was determined.

\section{Effect of sample color on counting efficiency}

The assays were carried out using 100 nCi $\left[{ }^{3} \mathrm{H}\right]$-thymidine or $\left[{ }^{14} \mathrm{C}\right]$-glucose diluted in $1 \mathrm{ml}$ of water in the presence or absence of 0.1 or $1 \mathrm{mg} / \mathrm{ml}$ Trypan blue. Next, $5 \mathrm{ml}$ of the scintillation liquids Insta-Gel-XF, Optiphase 
Figure 1. Effect of aqueous solution volume on the efficiency of $\left[{ }^{14} \mathrm{C}\right]$-glucose $(\mathrm{A})$ and $\left[{ }^{3} \mathrm{H}\right]$-thymidine (B) counting. Each point indicates the mean \pm SEM $(N=$ 4). (The error bars are too small to be visible). ${ }^{*} \mathrm{P}<0.05 \mathrm{com}-$ pared to the Insta-Gel-XF group (ANOVA followed by NewmanKeuls test). The linear reduction in the efficiency of $\left[{ }^{3} \mathrm{H}\right]$-thymidine counting (solid lines in panel B) was similar for all scintillation liquids used. DPM = disintegration per minute.
HiSafe 3 and Ultima-Gold ${ }^{\mathrm{TM}}$ AB were added to the vials.

\section{Results}

Effect of aqueous solution volume on ${ }^{14} \mathrm{C}$ and ${ }^{3} \mathbf{H}$ counting efficiency

As shown in Figure 1A, when the proportion of water varied from 0 to $33 \%$ of total volume, the efficiency of $\left[{ }^{14} \mathrm{C}\right]$-glucose counting was not significantly changed, regardless of the scintillation fluid used. However, when the samples were diluted in $3.0 \mathrm{ml}$ of water, which corresponds to $50 \%$ of the final volume, there was a significant reduction (55\%) in counting efficiency with the Optiphase HiSafe 3 scintillation liquid.

The increase in the relative amount of water in the samples induced a linear reduc-

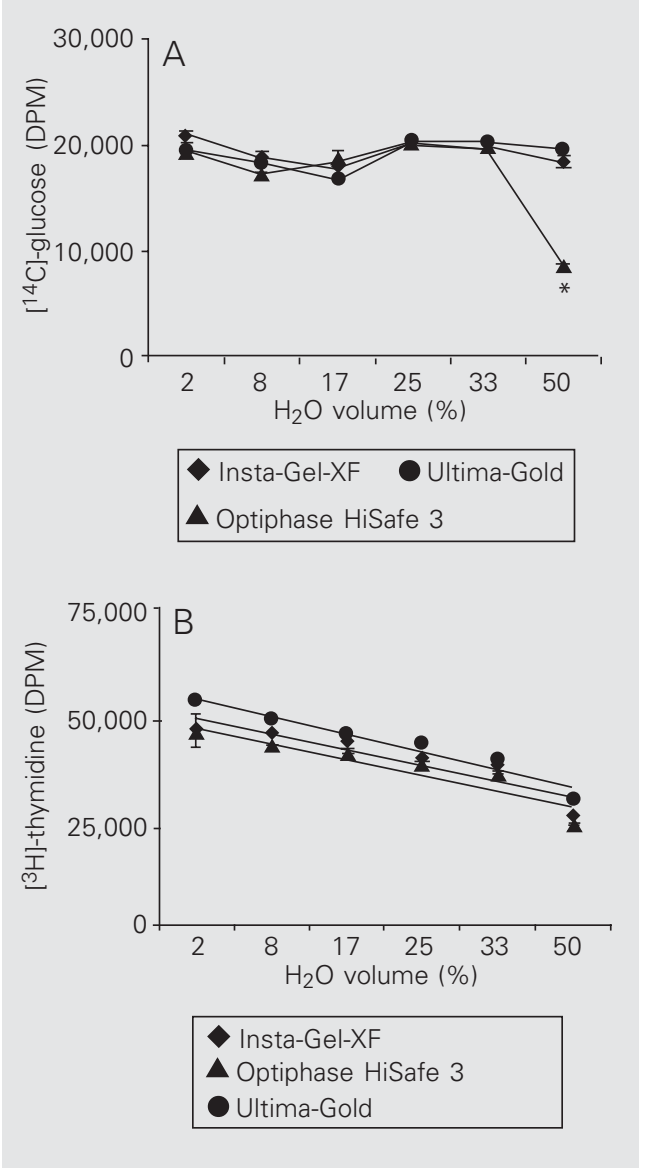

tion in the efficiency of $\left[{ }^{3} \mathrm{H}\right]$-thymidine counting, with similar slopes for all scintillation liquids used, as shown in Figure 1B.

Effect of concentration of radioactive samples on ${ }^{14} \mathrm{C}$ and ${ }^{3} \mathrm{H}$ counting efficiency

Regardless of the scintillation liquid used, the radioactivity detected was proportional to the $\left[{ }^{14} \mathrm{C}\right]$-glucose and $\left[{ }^{3} \mathrm{H}\right]$-thymidine concentration used, as shown in Figure $2 \mathrm{~A}$ and $\mathrm{B}$, respectively.

\section{Effect of sample $\mathrm{pH}$ on ${ }^{14} \mathrm{C}$ and ${ }^{3} \mathrm{H}$ counting efficiency}

The changes in solution $\mathrm{pH}$ did not influence the efficiency of $\left[{ }^{14} \mathrm{C}\right]$-glucose counting. On the other hand, when Optiphase HiSafe 3 and Ultima-Gold ${ }^{\mathrm{TM}} \mathrm{AB}$ were used at low $\mathrm{pH}(2.0)$, the efficiency of $\left[{ }^{3} \mathrm{H}\right]$-thymidine counting was 9 and $20 \%$ lower with Ultima-Gold $^{\mathrm{TM}} \mathrm{AB}$ and Optiphase HiSafe 3 than that obtained using Insta-Gel-XF (Figure $3 \mathrm{~A}$ and $\mathrm{B}$ ).

\section{Effect of sample color on ${ }^{14} \mathrm{C}$ and ${ }^{3} \mathrm{H}$ counting efficiency}

In order to analyze the influence of color quenching on the counting efficiency, $\left[{ }^{14} \mathrm{C}\right]$ glucose and $\left[{ }^{3} \mathrm{H}\right]$-thymidine were diluted in $1 \mathrm{ml}$ of water containing 0.1 to $1 \mathrm{mg} / \mathrm{ml}$ Trypan blue. As shown in Figure 4A, the efficiency of $\left[{ }^{14} \mathrm{C}\right]$-glucose radioactive counting was reduced by $83 \%$ in the presence of $1 \mathrm{mg} / \mathrm{ml}$ but not of $0.1 \mathrm{mg} / \mathrm{ml}$ Trypan blue solution, regardless of the scintillation liquid. Similarly, for $\left[{ }^{3} \mathrm{H}\right]$-thymidine samples, the reduction at $1.0 \mathrm{mg} / \mathrm{ml}$ Trypan was approximately 94\% (Figure 4B).

\section{Discussion}

The widespread use of radioisotopes in medical and biological research has generated a large volume of solid, liquid and 
biological wastes that need special treatment for disposal. In order to minimize the production of hazardous radioactive liquid waste we compared the efficacy of non-biodegradable scintillation cocktails containing organic solvents with biodegradable ones. We compared the effectiveness of three commercially available scintillation cocktails on the detection of $\left[{ }^{14} \mathrm{C}\right]$-glucose and $\left[{ }^{3} \mathrm{H}\right]$-thymidine radioactivity and determined the effect of the most common problems associated with the liquid scintillation counting such as water volume variations, sample $\mathrm{pH}$ and color quenching.

The present study showed few significant differences in the efficiency of ${ }^{14} \mathrm{C}$ and ${ }^{3} \mathrm{H}$ counting when using biodegradable scintillation liquids Ultima-Gold ${ }^{\mathrm{TM}} \mathrm{AB}$ or Optiphase HiSafe 3 compared to a non-biodegradable one (Insta-Gel-XF), indicating that biodegradable cocktails do not impair the detection of radioactivity when used under appropriate conditions.

Except for the lower efficiency of $\left[{ }^{3} \mathrm{H}\right]-$ thymidine counting using Ultima-Gold ${ }^{\mathrm{TM}} \mathrm{AB}$ at $\mathrm{pH}$ 2.0, replacement of Insta-Gel-XF with biodegradable liquids resulted in a similar counting profile in terms of volume of aqueous solution, concentration of radioisotopes and variations in sample color and $\mathrm{pH}$. The reduced counting efficiency for tritium at extremely low $\mathrm{pH}$ (2.0) may have been related to the higher turbidity of the scintillation fluid at acidic $\mathrm{pH}$. This result, however, does not impair the use of Ultima-Gold ${ }^{\mathrm{TM}}$ $\mathrm{AB}$, but simply indicates that the sample $\mathrm{pH}$ should be corrected before counting.

The most relevant interference with counting efficiency was observed in the colored samples (Figure 4A,B). In general, color quenching results from the attenuation of photons during their passage through the medium (7). The reduction of counting efficiency was observed in samples containing the higher concentration of Trypan blue, $1 \mathrm{mg} / \mathrm{ml}$, regardless of the scintillation liquid used. It is therefore essential to monitor the

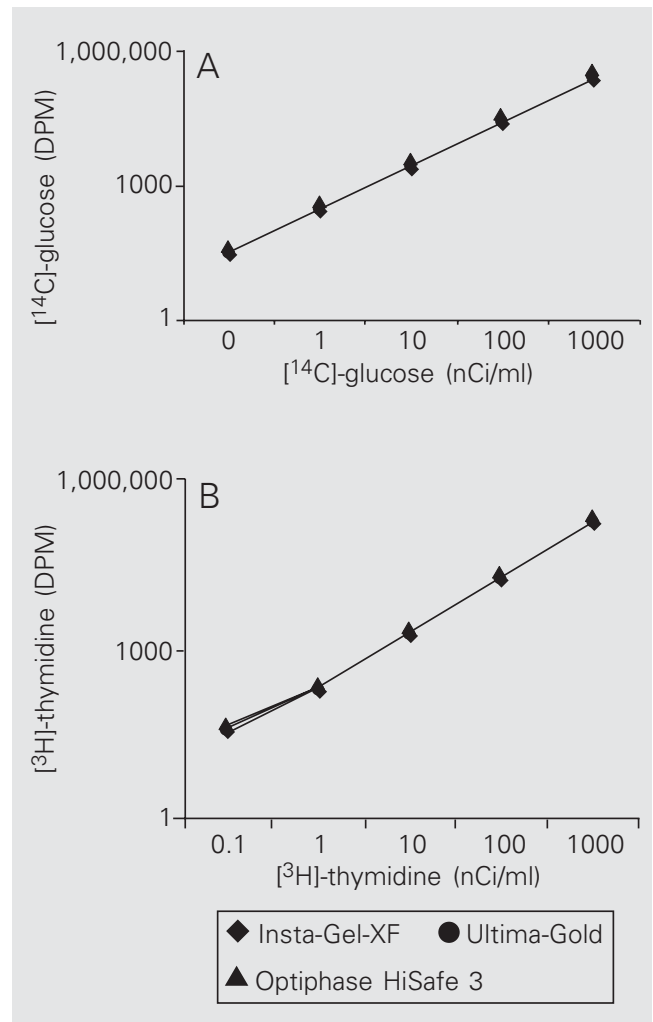

Figure 2. Effect of concentration of radioactive samples on the efficiency of $\left[{ }^{14} \mathrm{C}\right]$-glucose $(A)$ and $\left.{ }^{3} \mathrm{H}\right]$-thymidine $(\mathrm{B})$ counting. Each point indicates the mean \pm SEM $(N=4)$. (The error bars are too small to be visible). DPM = disintegration per minute.

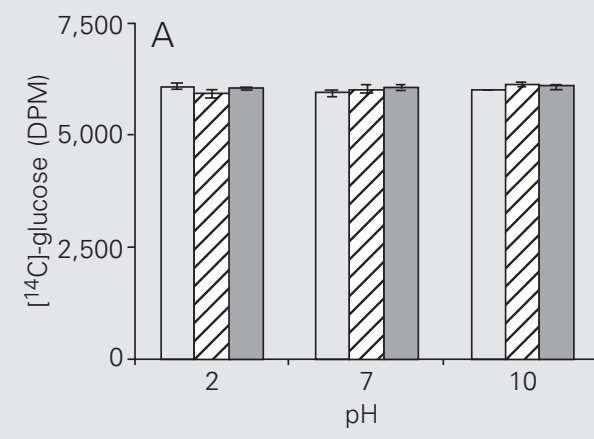

Figure 3. Influence of sample $\mathrm{pH}$ on the efficiency of $\left[{ }^{14} \mathrm{C}\right]-$ glucose (A) and $\left[{ }^{3} \mathrm{H}\right]$-thymidine (B) counting. Each point represents the mean \pm SEM $(N=4)$. (The error bars are too small to be visible) ${ }^{*} \mathrm{P}<0.05$ compared to the Insta-Gel-XF group (ANOVA followed by NewmanKeuls test). DPM = disintegration per minute.

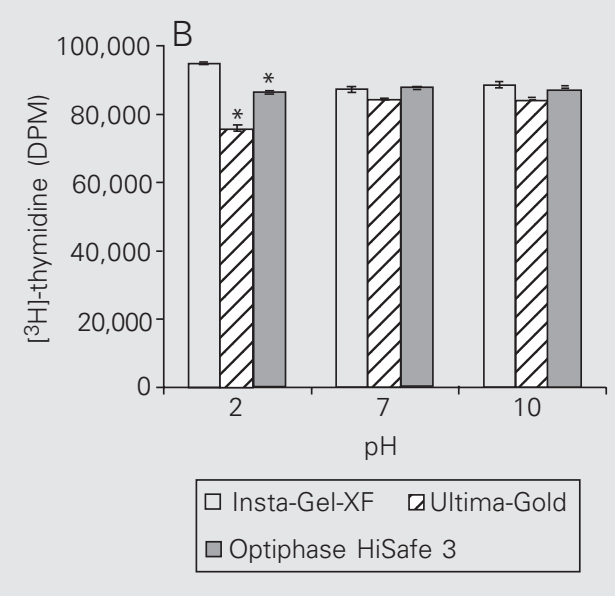


Figure 4. Influence of sample color on the efficiency of $\left[{ }^{14} \mathrm{C}\right]$ glucose $(\mathrm{A})$ and $\left[{ }^{3} \mathrm{H}\right]$-tritium $(\mathrm{B})$ counting. Each bar indicates the mean \pm SEM $(\mathrm{N}=4)$. (The error bars are too small to be visible). DPM = disintegration per minute.

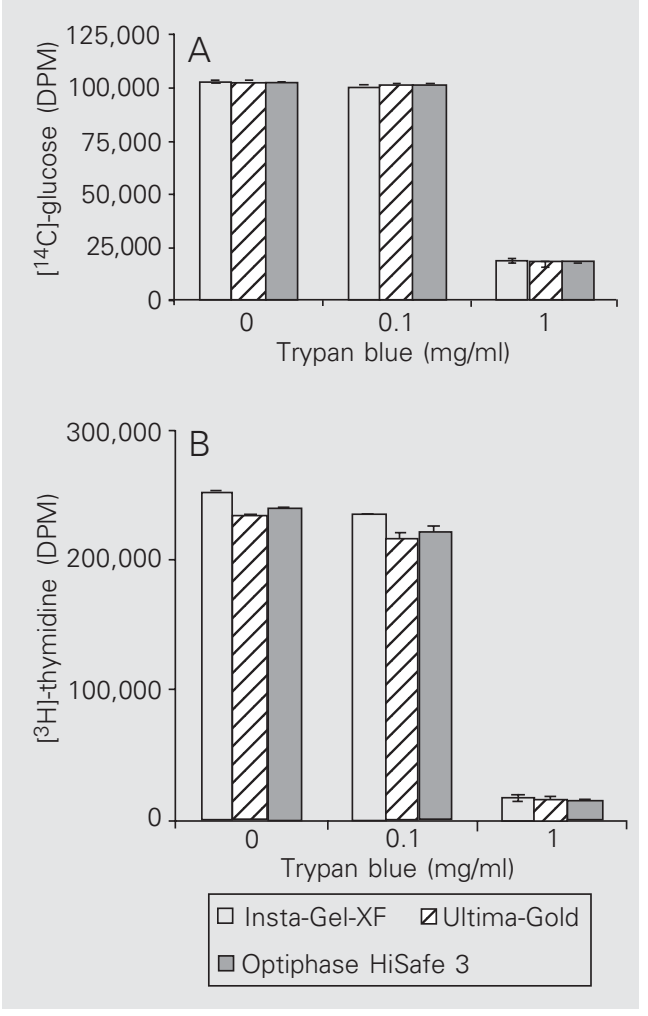

counting efficiency in colored samples, when a precise determination of radioactive molecules is necessary. In this case, standards of known radioactivity should be used to obtain a correction factor and to correct the color quenching.

Our data also showed that the quenching effect on counting efficiency is also dependent on the type of radioisotopes. The higher susceptibility of ${ }^{3} \mathrm{H}$ compared to ${ }^{14} \mathrm{C}$ might be explained by the lower energy of tritium that reduces the efficiency of energy transfer to the solvent molecules (1).

The fundamental advantage of using biodegradable scintillation cocktails is related to the disposal of radioactive residues. For the non-biodegradable product it is necessary to request the chemical analysis of the waste sample according to the Brazilian Standard Rules and to obtain the industrial waste registration document required by the environmental agency (Companhia de Tecnologia de Saneamento Ambiental, CETESB) $(8,9)$. It is also relevant to take into account the cost of waste disposal, which includes the storage and treatment of toxic residues. On the other hand, non-hazardous aqueous radioactive wastes that are readily soluble in water may be disposed of via the sanitary sewage system if the concentration and maximum disposal radioactivity limits are observed $\left(3.7 \times 10^{9} \mathrm{~Bq} / \mathrm{m}^{3}\right.$ or $0.1 \mu \mathrm{Ci} / \mathrm{ml}$ for ${ }^{3} \mathrm{H}$, or $7.4 \times 10^{8} \mathrm{~Bq} / \mathrm{m}^{3}$ or $0.02 \mu \mathrm{Ci} / \mathrm{ml}$ for ${ }^{14} \mathrm{C}$ ) according to the criteria outlined by CNEN. In fact, if the concentration of radioactive waste is below these limits, the waste is no longer characterized as radioactive but is considered to belong to the chemical group of waste defined as Class I Hazardous based on the Brazilian Standard Rules (ABNT NBR-10004 and 10007).

The present results show that traditional hazardous scintillation fluids can be replaced with safe biodegradable ones. The benefits of using environmentally benign fluids include the reduction of both liquid and solid radioactive waste since the containers of hazardous solvents must also be stored for later incineration. In addition to reducing the overall cost of radioactive waste disposal, the use of biodegradable scintillation cocktails minimizes both human and environmental exposure to hazardous solvents. In addition, some biodegradable scintillation liquids can be $40 \%$ less expensive than the traditional hazardous cocktails (see Table 1).

\section{Acknowledgments}

We thank the Natural Products Section, Department of Pharmacology, UNIFESP/ EPM, for the use of laboratory facilities. 


\section{References}

1. Bitelli T (1982). Noções de física nuclear. In: Bitelli T (Editor), Dosimetria e Higiene das Radiações. Grêmio Politécnico, São Paulo, SP, Brazil, 27-237.

2. Carvalho PR (1999). Produtos químicos e seus efeitos. In: Carvalho PR (Editor), Boas Práticas Químicas em Biossegurança. Interciência, Rio de Janeiro, RJ, Brazil, 79-85.

3. Comissão Nacional de Energia Nuclear, Norma CNEN-NE.6.05 (1985). Gerência de rejeitos. In: Comissão Nacional de Energia Nuclear (Editor), Gerência de Rejeitos Radioativos em Instalações Radiativas, Resolução CNEN 19/85. CNEN, Rio de Janeiro, RJ, Brazil, 7-11.

4. Comissão Nacional de Energia Nuclear (1998). Rejeitos radioativos oriundos de atividades de pesquisa. In: Comissão Nacional de Energia Nuclear (Editor), Programa de Gerência de Rejeitos Radioativos em Pesquisa. CNEN, Rio de Janeiro, RJ, Brazil, 13-15.
5. Meechan PJ (1997). Color quenching in "environmentally friendly" cocktails. Health Physics, 73: 808-813.

6. De Vol TA, Brown DD, Leyba JD \& Fjeld RA (1996). A comparison of four aqueous-miscible liquid scintillation cocktails with an alpha/ beta discriminating Wallac 1415 liquid scintillation counter. Health Physics, 70: 41-46.

7. Neame KD (1978). Sources of error in the channels ratio method for efficiency determination in liquid scintillation counting. Analytical Biochemistry, 91: 323-339.

8. Associação Brasileira de Normas Técnicas (1995). ABNT. NBR 10004. Resíduos Sólidos - Classificação. ABNT, Rio de Janeiro, RJ, Brazil.

9. Associação Brasileira de Normas Técnicas (1995). ABNT. NBR 10007. Amostragem de Resíduos - Procedimento. ABNT, Rio de Janeiro, RJ, Brazil. 